\title{
Rules for Rights: European Law, Health Care and Social Citizenship
}

\author{
Scott L. Greer* and Tomislav Sokol**
}

\begin{abstract}
Social citizenship is about equality. The obvious problem for European social citizenship in a very diverse Union is that Member States will not be able or willing to bear the cost of establishing equal rights to health care and similar aspects of social citizenship. Health care is a particularly good case of this tension between EU citizenship and Member State diversity. The European Court of Justice (ECJ) strengthened the right to health care in other Member States, but this cannot create an equal right to health care when Member States are so different. In its efforts to balance a European right, the Court has formulated 'rules for rights'-not so much European social citizenship rights, as a set of legal principles by which it judges the decisions of the Member States.
\end{abstract}

\section{The Problem of European Social Citizenship}

\section{A The Problem: The Tension between European Citizenship and Diversity}

T. H. Marshall's legendary lectures on citizenship rights divided citizenship into three kinds of rights: civil rights to free movement, speech, and assembly; political rights to participation, above all the ballot; and social rights to equal provision of things necessary to dignified participation in society such as housing, health care and legal representation. ${ }^{1}$ The common denominator is that they are egalitarian: citizenship rights such as the right to health care or to vote apply equally to rich and poor, thereby making inequality in the rest of society more bearable. One need not adopt Marshall's argument that they come in a logical sequence (civil rights beget political rights, which beget social rights) to see them as different kinds of rights with different political causes, legal manifestations and policy consequences.

The EU appears to fit neatly into the framework; and for that matter the sequence. The 'constitutional' rights to freedom of movement of goods, services, capital and people are in large part civil rights. EU citizens mostly have the right to travel to, work in and conduct their lives in another EU Member State. Formal EU citizenship

\footnotetext{
* Associate Professor, Department of Health Management and Policy, School of Public Health, University of Michigan, Ann Arbor, MI, USA.

** Lecturer, Zagreb School of Economics and Management/PhD Researcher, Catholic University of Leuven, Zagreb, Croatia.

1 T. Marshall, Citizenship and Social Class (Pluto, 1950); A. Rees, 'T.H. Marshall and the Progress of Citizenship', in M. Bulmer and A. Rees (eds), Citizenship Today: The Contemporary Relevance of T.H. Marshall. (UCL Press, 1996), at 1-24; P. Breiner, 'Is Social Citizenship Really Outdated? T. H. Marshall Revisited', (Mar 16, 2006) Western Political Science Association; S. Greer, Devolution and Social Citizenship in the United Kingdom (Policy Press, 2009).
} 
enshrines these rights. Attained by virtue of having citizenship in a Member State, it grants a range of civil rights across borders. ${ }^{2}$ It also starts to create political rights, above all limited (local and European Parliament) rights to political participation. ${ }^{3}$

Social rights are distinct from civil and political rights in a number of ways. ${ }^{4}$ They are expensive. Adding resident foreigners to local electoral rolls is a small cost; funding health care or housing is potentially a much larger cost. Their delivery is complex. Health, education and welfare bureaucracies are less costly and often more efficient when dealing with predictable and homogeneous populations whose numbers, needs, provisioning and behaviour can be anticipated.

The result is that establishing social citizenship rights at the EU level demands overcoming two major problems. The first problem is that these costs make EU, or other international social policy, difficult because they involve redistribution that might not be politically possible. ${ }^{5}$ Expanding the scope of social rights and the numbers of citizens have costs that show up in government budgets, service delivery and in many cases popular perception. The costs of expanding social rights and the complexity of delivering them also creates opportunities for social friction; it is not clear that people are all equally open to paying taxes in order to provide services for people from other countries. Nor is there much documented support for the approximation of different welfare states' models of delivery and entitlements. Finally, even if those problems were easily surmountable, the most important is the very large disparities between EU Member States. The resources that Bulgaria and Germany can devote to social citizenship are very different. As a result, a commitment to European social citizenship seems far-fetched. If equality is the essence of citizenship, then it is not easy to see how the highly unequal EU Member States are going to develop equal social citizenship.

Second, social citizenship rights are a bad fit with the institutional and historical structure of the EU. The EU is a regulatory state, acting primarily through law to change the behaviour of others. ${ }^{6}$ Its budget is a trivially small part of the EU economy and mostly directed to agriculture and regional development rather than the kinds of large-scale social spending that would make it a real contributor to social citizenship. The EU budget historically hovers around $1 \%$ of gross domestic product (GDP); Member States' publicly financed health care starts around 6\% of GDP. This regulatory EU state, which can make rules affecting states but not provide resources, is a good fit with a jurisprudence based around civil citizenship rights to movement and participation in markets. It explains why the EU has historically been so effective at negative integration, and its efforts at positive integration have mostly involved developing EU-level regulation rather than transfers or direct spending. Such a regulatory state, best at affecting the things other people do with their money and legally strongest when engaged in negative integration, does not seem well adapted to creating egalitarian social citizenship rights. Furthermore, such changes would almost certainly have to come through EU legislation and budgeting; it is not apparent that

\footnotetext{
2 A. Wiener, 'From Special to Specialized Rights: The Politics of Citizenship and Identity in the European Union', in M. Hanagan and C. Tilly (eds), Extending Citizenship, Reconfiguring States (Rowman \& Littlefield, 1999), at 195-228.

3 J. Shaw, The Transformation of Citizenship in the European Union (Cambridge University Press, 2007).

${ }^{4}$ D. Wincott, 'Social Policy and Social Citizenship: Britain's Welfare States', (2006) 36 Publius 169.

5 A. de Swaan, 'The Prospects for Transnational Social Policy: A Reappraisal', in Hanagan and Tilly, op cit $\mathrm{n} 2$ supra, at $179-194$.

${ }^{6}$ G. Majone, Regulating Europe (Routledge, 1996).
} 
the Court would have many ways to improve the quality of social citizenship (eg education, housing, health, income replacement, pensions). The result is that many scholars who have looked at the EU and the welfare state, or the EU and social citizenship specifically, have been sceptical of its potential. ${ }^{7}$

How, then, does the ECJ's technique of expanding access to health care in other countries cope with the many policy problems that arise and with the broad threat to social citizenship rights that comes from increasing exit options without increasing solidarity? How does it expand the right to provide and receive health care across borders without damaging solidarity within and between Member States?

\section{B The Court's Answer: Rules for Rights}

We argue that the ECJ has developed a second-order jurisprudence of social citizenship rights and therefore of EU social citizenship as a set of rules for determining the legitimate content of Member States' social citizenship rights. Instead of setting fixed standards for health-care quality and access, which people could use as a justification for going abroad, it is moving towards 'rules for rights': setting principles by which to judge the rules Member States use to make decisions about social rights. Instead of trying to actively set standards for quality or access, its decisions set the standards for judging the legality of a state's standards. It avoids the creation of meaningful (expensive, politically difficult) EU-wide rules by instead obliging Member States to follow EU rules when establishing social rights. It allows the EU a say in social citizenship without obliging it to define or fund real rights that all Europeans would share.

\section{Rules for Rights in Other Areas of Law}

Health care is not the only area where the establishment of an EU-wide approach is complicated by the divergence between Member States and the institutional limitations of a regulatory polity, so it is not surprising that the approach can be found elsewhere. Perhaps the most worked out areas of the Court's approach is in competition law's applicability to social welfare. The problems and law are clearly not identical; in free movement there is a relationship between a Member State and an individual, evaluated by the Court of Justice, mostly from the point of view of individual who is invoking his/her EU law right. The situation is somewhat different in the area of competition, where there is, generally, a direct relationship between an individual (breaching EU law) and the EU law. In such a case, concrete standards need to be developed by EU law to deal with the issue. The parallels between the Court's approach in competition and health care therefore show the wider use of the approach in different areas.

In the field of competition law, an area where the Court allows Member States to determine certain standards is the area of classifying an entity as an 'undertaking,' which

\footnotetext{
${ }^{7}$ M. Hoepner and A. Schaefer. 'Eine Neue Phase der Europaeischen Integration: Legitimtaetsdefinizite Europaeischer Liberalisierungspolitik', in M. Hoepner and A. Schaefer (eds), Die Politische Oekonomie der Europaeischen Integration (Campus, 2008), at 129-257; F. Scharpf. 'The European Social Model: Coping with the Challenges of Diversity', (2002) 40 Journal of Common Market Studies 645; M. Kleinman. A European Welfare State? European Union Social Policy in Context (Palgrave, 2002); P. Leibfried, European Social Policy: Between Fragmentation and Integration (Brookings Institution, 1995).
} 
is a prerequisite for the applicability of EU competition rules to the entity in question. When certain privileges are given by the state to an entity whose actions are determined and controlled by the state, the entity has a social purpose ${ }^{8}$ and operates according to the principle of solidarity, ${ }^{9}$ that entity is not an undertaking. The principle of solidarity exists where, for instance, a person's earnings are taken into consideration for determining the amount of his/her mandatory contributions to the insurance association. ${ }^{10}$

The Court of First Instance (now the General Court) defined solidarity in FENIN ${ }^{11}$ (upheld by the Court of Justice ${ }^{12}$ ) as behaviour antithetical to market behaviour and found the entity in question not to represent an undertaking. The indication of solidarity in that case was the free-of-charge provision of services, meaning the lack of market exchange between the national health authority and the patients. The Court inferred solidarity from the nature of the transaction between the service provider, financed by way of supply-side subsidies ${ }^{13}$ and the recipient. Free provision of services is often redistributive and progressive, and solidarity is, obviously, closely connected to redistribution.

The state can, for instance, prohibit competition at the outset in favour of a state body that is performing a social function, based on the principle of solidarity, and whose actions are regulated through state legislation (by prescribing mandatory affiliation and setting contribution rates). In Freskot, the party was part of the state with no independence in determining the contributions it had to be paid. The amount was determined by legislation, and the entity was declared not to be an undertaking within the meaning of the EU primary law. ${ }^{14}$

This jurisprudence implies that national legislation is important when it virtually closes the market for competition, regulating an activity in a way which makes it completely unfeasible for private persons to competitively take part in it. In those situations, there is no adverse effect on private entrepreneurs, because they have been banned from the market at the outset. Thus, existence of a market effectively open to competition represents the decisive factor for application of competition rules. ${ }^{15}$

However, some other aspects are also taken into account when determining whether competition rules are applicable, in relation to the EU primary law rules on

${ }^{8}$ Case C-355/00 Freskot AE v Elliniko Dimosio [2003] ECR I-5263 para 77.

${ }^{9}$ Case C-350/07 Kattner Stahlbau GmbH v Maschinenbau- und Metall- Berufsgenossenschaft [2009] ECR I-1513 para 43; See, also, Case C-218/00 Cisal di Battistello Venanzio \& C. Sas v Istituto nazionale per l'assicurazione contro gli infortuni sul lavoro (INAIL) [2002] ECR I-691 and Case C-437/09 AG2R Prévoyance v Beaudout Père et Fils SARL [2011] ECR I-973.

10 Kattner, ibid, para 45.

11 Case T-319/99 Federación Nacional de Empresas de Instrumentación Científica, Médica, Técnica y Dental (FENIN) v Commission of the European Communities [2003] ECR II-357 para 39.

12 Case C-205/03 Federación Española de Empresas de Tecnología Sanitaria (FENIN) v Commission of the European Communities [2006] ECR I-6295.

13 On supply-side and demand-side subsidies, see G. Davies, 'Competition, Free Movement, and Consumers of Public Services', (2006) 17 European Business Law Review 95.

14 Freskot, op cit n 8 supra, at para 78.

15 This position was also taken by the Court of First Instance (General Court) in Case T-168/01 GlaxoSmithKline Services Unlimited v Commission of the European Communities [2006] ECR II-2969 (upheld by the Court of Justice in Joined cases C-501/06 P, C-513/06 P, C-515/06 P and C-519/06 P GlaxoSmithKline Services Unlimited v Commission of the European Communities [2009] ECR I-9291) para 105; On exclusion of competition by compelling sickness funds to offer their members identical obligatory benefits which do not depend on the amount of the contributions and by equalising risks and costs between different funds, see Joined cases C-264/01, 306/01, 354/01 and 355/01 AOK-Bundesverband and Others $v$ Gödecke GmbH and Others [2004] ECR I-2493. 
undertakings to which Member States grant special or exclusive rights. These aspects include the issue of whether activities have always been, and whether they are necessarily carried out by such undertakings or by public authorities. If that is not the case, the activity in question is an economic one, resulting in applicability of EU competition law. ${ }^{16}$

Generally, the Court of Justice does not determine which concrete areas can or cannot be excluded from application of EU competition law by national authorities. That freedom is left to Member States. However, when doing that, the Member States must satisfy certain criteria recognised as relevant by the Court.

In the area of state aid, a Member State is the one breaching the EU law on behalf of an individual (against the latter's individual competitors not granted state aid). EU law focuses on regulating the ability of Member States to make policies in its grey areas. This means that 'rules for rights' is visible in the case-law on state aid. The Altmark decision is particularly important. The Court stated in Altmark that certain public subsidies, which represent compensation for the services provided by the recipient undertakings in order to discharge public service obligations, are not incompatible with EU rules on state aid (are not state aid in the sense of a Article 107 of the Treaty on the Functioning of the European Union (hereinafter: TFEU, former Treaty Establishing the European Community) ) if several conditions are met. ${ }^{17}$

Within that framework, Member States are free to decide on the manner in which compensation for exercising public service obligation will be given to an undertaking, provided they satisfy the objectivity, transparency and necessity criteria. Furthermore, Member States are free to determine by themselves the concrete public services obligations (but have to do that from the start, not ex post), provided they fulfil the requirements set out by the EU courts and the relevant EU secondary law. ${ }^{18}$ The Court sets the rules that translate into Member States' establishment of rights and remedies.

\section{EU Cross-Border Health Legal Framework and Social Rights to Health}

Health care services is one area in which the ECJ has been leading the creation of new European rights. It is an important, and evolving, exercise that can tell us whether and how the ECJ can contribute to the development of European social citizenship. Some approaches to ECJ health jurisprudence are laudatory. Caporaso and Tarrow, for example, argue that the extension of rights to health care in other countries adds a social dimension to European citizenship by giving people's freedom of movement

16 Case C-475/99 Ambulanz Glöckner v Landkreis Südwestpfalz [2001] ECR I-8089 para 20; This was the case where a private provider had been actually carrying out the service in question, but the renewal of its authorisation was denied under the new national legislation (to favour public undertakings).

17 Case C-280/00 Altmark Trans GmbH, Regierungspräsidium Magdeburg $v$ Nahverkehrsgesellschaft Altmark GmbH [2003] ECR I-7747 para 95.

18 See, also, the Court of First Instance (General Court) approach in T-289/03 British United Provident Association Ltd (BUPA), BUPA Insurance Ltd, BUPA Ireland Ltd v Commission of the European Communities [2008] ECR II-81, especially paras 165-170, 190; On the definition of public service obligation, see Regulation (EC) 1370/2007 of the European Parliament and of the Council of 23 October 2007 on public passenger transport services by rail and by road, and repealing Council Regulations (EEC) No 1191/69 and (EEC) No 1107/70 [2007] OJ L315/1 (Public Passenger Transport Regulation 2007) art 2. A similar definition was present in the repealed Regulation (EEC) 1191/69 of the Council of 26 June 1969 on action by Member States concerning the obligations inherent in the concept of a public service in transport by rail, road and inland waterway [1969] OJ L156/1, as amended. 
more content and balancing the large amount of market-making law. ${ }^{19}$ The European Commission has said much the same thing, emphasising in its publicity the freedom to get health care in other states. Most comments from health law and policy, however, show much more worry. ${ }^{20}$ Maurizio Ferrera put the problem best: EU health-care services jurisprudence has a 'destructuring' and 'deterritorialising' effect on welfare states by increasing exit options for the wealthy or strategic. ${ }^{21}$ This does not just limit redistribution, risk pooling and solidarity by allowing some people to shop for taxes and services; it also interferes with the complex administrative mechanisms that allow social policy to work (eg capacity planning).

This section aims to provide a brief overview of EU legal framework on social coverage of health treatments which are obtained by patients who travel outside their state of social insurance (competent state) specifically to receive health-care treatments. The framework includes the EU regulations on coordination of social security systems, the case-law of the Court of Justice applying directly internal market Treaty provisions and the recent Patient Mobility Directive. Before that, however, the general place of social security and health care within the EU primary law must be explained.

\section{A Primary Law}

It is first necessary to examine the Treaty on European Union (hereinafter: TEU) and TFEU. EU competences in the field of social security and health care are limited. In the area of public health, the Union respects 'responsibilities of the Member States for the definition of their health policy and for the organisation and delivery of health services and medical care,' according to the Article 168(7) TFEU. Union action concerning protection and improvement of human health can only support and complement Member States' policies, according to the Article 6 TFEU. Only in certain limited areas (like safety standards for medicinal products) does the EU have a significant regulatory competence, according to the Article 168(4) TFEU and shares competence with Member States regarding common safety concerns in public health matters, for the aspects defined in the Treaty, according to the Article 4 TFEU.

A similar situation exists in the area of social policy, especially concerning social security. Social policy is, generally, one of the competences shared between the EU and the Member States (for the aspects defined in the Treaty), according to the Article 4 TFEU. However, that provision does not give concrete powers to the EU to adopt legally binding measures related to social security. When we look at the Article 153 TFEU, which is the legal basis for the Union to act in social fields, including social security, we can observe three things.

First, Union measures can still only complement and support Member States' actions. Second, EU measures in this area 'shall not affect the right of Member States

19 J. Caporaso and S. Tarrow, 'Polanyi in Brussels: Supranational Institutions and the Transnational Embedding of Markets', (2009) 63 International Organization, 593.

${ }^{20}$ C. Newdick, 'The European Court of Justice, Trans-National Health Care, and Social CitizenshipAccidental Death of a Concept?' (2009) 26 Wisconsin International Law Journal 844; S. Greer, 'Ever Closer Union: Devolution, the European Union, and Social Citizenship Rights', in S. Greer op cit n1 supra; A. Pollock, NHS Plc: The Privatisation of Our Health Care (Verso, 2004). Their arguments mirror the general ones in $\mathrm{n} 7$ supra.

${ }^{21}$ M. Ferrera, 'Beyond National Social Rights?', in N. McEwen and L. Moreno (eds), The Territorial Politics of Welfare (Routledge, 2005), at 225-243. 
to define the fundamental principles of their social security systems and must not significantly affect the financial equilibrium thereof'. Third, decision making related to social security is subject to unanimous vote in the Council, which can only be changed by amending the Treaty. So, the Member States retain their autonomy to define social security coverage of health care by themselves. ${ }^{22}$

The Union can also adopt rules concerning coordination of social security systems of Member States. These rules aim at facilitating free movement of persons within the EU by ensuring that they do not loose social security entitlements due to their cross-border movement. The adoption of the coordination rules is subject to unanimous decision making, regarding economically non-active persons (Article 21(3) TFEU). For economically active persons (Article 48 TFEU), decision making in the Council is carried out through qualified majority, but any single Member State can block that process by invoking a danger to an important aspect of its social security system. When that happens, the process shifts to the European Council, which decides unanimously. This unanimity requirement for social security will continue to be the main obstacle to creating any concrete social (redistributive) rights on the European level. ${ }^{23}$

It is, also, worth noting that the Charter of Fundamental Rights of the EU has formally become part of the EU primary law according to the Article 6 TEU reference. It recognises entitlement to social security benefits in its Article 34, in accordance with Union law and national law and practices, and the right to benefit from medical treatment under the conditions established by national law and practices in its Article 35. The Charter only reaffirms the rights already present within the EU legal framework. It applies in cases where EU competences exist and is addressed to the Member States only when they are implementing the Union law without changing the division of competences prescribed by the Treaty. Taking all this into account, and also the not completely clear distinction between rights and principles enshrined in the Charter, its practical legal role remains ambiguous. ${ }^{24}$

We can see that the possibilities of Union action in the area of social security and health care are very constrained. One of the fields in which the EU has, indeed, acted and directly touches upon cross-border planned health care, is social security coordination, which we turn to next. It shows the limited ability of the EU to create social citizenship rights in Marshall's sense, ie equality of entitlements in key areas.

\section{B Social Security Coordination}

The issue of social security coverage in situations of persons travelling abroad, for a specific purpose of obtaining health care, has been regulated by the European law since the very start of the integration process via EU secondary legislation (directly

\footnotetext{
22 See Article 153 Treaty on the Functioning of the European Union (TFEU).

${ }^{23}$ ibid, Article 21(3), 48, 153 and Article 15(4) Treaty on European Union (TEU).

${ }^{24}$ See Preamble to the Charter of Fundamental Rights of the European Union, Charter's Art 51-52 and C. Hilson, 'Rights and Principles in EU Law-A Distinction without Foundation?' (2008) 15 Maastricht Journal of European and Comparative Law 193.
} 
applicable regulations) on coordination of social security systems. The underlining idea of the regulations is to resolve situations when a person comes into contact with several national social security (legal) systems. In these cases problems may occur, namely of losing one's social security entitlements. To resolve these conflicts of laws, the EU social security coordination has been established. It only affects those national provisions which deal with migrants, specifically by overriding the national rules which are disadvantageous to them. Member States remain free to decide on the range of health care that is to be covered. ${ }^{25}$

These regulations have provided for competent state coverage of foreign treatments under the condition of the patient acquiring prior authorisation by that state. The cost of the treatment in question is then paid by the competent state, directly to the state of treatment, on basis of the latter's tariffs (the patient only has to pay a co-payment if the latter is prescribed by the state of treatment legislation for its population). ${ }^{26}$

The system of coordination is controlled by the national social security institutions. Because of that, prior authorisation is a rule, with limited exceptions stemming from the Court of Justice jurisprudence (concerning urgency of a treatment). The patient can only access providers who are affiliated (employed or contracted by) to the state of treatment social security system. ${ }^{27}$ When the national legislation of the competent state prescribes reimbursement of the costs of travel and stay, which are inseparable from the treatment of the patient, such costs for the person concerned and, if necessary, for a person who must accompany him/her, must be covered by the competent state. $^{28}$

\section{Case-Law}

The Court of Justice patient mobility jurisprudence has been extensively analysed in the literature. ${ }^{29}$ We shall not engage in detailed description of every case concerning

${ }^{25}$ See, for instance, Regulation (EEC) 1408/71 of the Council of 14 June 1971 on the application of social security schemes to employed persons and their families moving within the Community [1971] OJ L149/2, as amended (Regulation 1408/71), replaced by Regulation (EC) 883/2004 of the European Parliament and of the Council of 29 April 2004 on the coordination of social security systems [2004] OJ L166/1, as amended (Regulation 883/2004), adopted on basis of Article 42 EC (equivalent to today's Article 48 TFEU) and Article 308 EC (equivalent to today's Article 352 TFEU, which entitles the EU to act if the Union action should prove necessary, within the framework of Treaty defined policies, to attain one of the Treaty objectives, and the Treaties have not provided necessary powers); See, also, Regulation (EC) 987/2009 of the European Parliament and of the Council of 16 September 2009 laying down the procedure for implementing Regulation (EC) 883/2004 on the coordination of social security systems [2009] OJ L284/1, as amended (Regulation 987/2009); See, also, F. Pennings, Introduction to European Social Security Law (Intersentia, 4th edn, 2003), at 7 .

${ }^{26}$ See Art 2, Reg 883/2004, op cit n 25 supra.

${ }^{27}$ See Art 20, Reg 883/2004, op cit n 25 supra, Case C-173/09 Georgi Ivanov Elchinov v Natsionalna zdravnoosiguritelna kasa [2010] ECR I-8889 paras 43-51 and Case C-512/08 European Commission v French Republic [2010] ECR I-8833 para 27.

28 See Art 26(8) Reg 987/2009, op cit $\mathrm{n} 25$ supra.

${ }^{29}$ For instance, P. Cabral, 'Cross-Border Medical Care in the European Union: Bringing Down a First Wall', (1999) 24 European Law Review 387; P. Cabral, 'The Internal Market and the Right to Cross Border Medical Care', (2004) 29 European Law Review 673; M. Flear, 'Case C-385/99 V.G. Müller-Fauré v. Onderlinge Waarborgmaatschappij O.Z. Zorgverzekeringen.UA and E.E.M van Riet v. Onderlinge Waarborgmaatschappij Z.A.O. Zorgverzekeringen, Judgement of the Court of 13 May 2003', (2004) 42 
the area but rather focus on some crucial aspects of the jurisprudence in question. In this section, some basic issues will be presented, while the Court's 'rules for rights' approach will be explained in detail in the following section.

The first step the Court of Justice took was to allow for the application of internal market rules to the area of social security coverage of health care. The applicability of four freedoms provisions of EU primary law to health care is not new. It was already held in Luisi and Carbone that 'tourists, persons receiving medical treatment and persons travelling for the purposes of education or business are to be regarded as recipients of services. ${ }^{30}$ A logical conclusion of the judgement in question is that EU primary law rules on free provision of services apply to the field of health care. The Court explicitly affirmed this interpretation in Grogan. ${ }^{31}$

What has been debated for years, however, is to what extent internal market law can apply to the complicated and politically sensitive world of national social security health-care systems. A groundbreaking judgement in this respect was Raymond Kohll $v$ Union des caisses de maladie. There, the Court explicitly stated that freedom to provide services, one of the pillars of the internal market law of the EU, applies to the social security health-care area. ${ }^{32}$

The crucial reason for the applicability of free provisions of services to social health care is, according to the Court of Justice, the cross-border nature of the treatment. This means that a patient travels abroad to obtain a health treatment, pays on the spot to the foreign provider and claims reimbursement afterwards by the social security institution in the state in which he/she is socially protected. The basis for the applicability of internal market law is the transaction between the patient and the

Common Market Law Review 209; S. L. Greer, 'Migration of Patients and Migration of Power: Politics and Policy consequences of Patient Mobility in Europe', (2009) 26 Wisconsin International Law Journal 908; V. Hatzopolous, 'A (More) Social Europe: A Political Crossroads or a Legal One-Way? Dialogues between Luxembourg and Lisbon', (2005) 42 Common Market Law Review 1599; V. Hatzopoulos, 'Killing National Health and Insurance Systems but Healing Patients? The European Market for Health Care Services after the Judgements of the ECJ in Vanbraekel and Peerbooms', (2002) 39 Common Market Law Review 683; Y. Jorens, M. Coucheir and F. Van Overmeiren, 'Access to Health Care in an Internal Market: Impact for Statutory and Complementary Systems', (2005) 18 Bulletin Luxembourgeois des Questions Sociales 1; A. Kaczorowska, 'A Review of the Creation by the European Court of Justice of the Right to Effective and Speedy Medical Treatment and Its Outcomes', (2006) 12 European Law Journal 345; C. Newdick, 'Citizenship, Free Movement and Health Care: Cementing Individual Rights by Corroding Social Solidarity', (2006) 43 Common Market Law Review 1645; Newdick (2009) op cit n 20 supra; J. van de Gronden, 'Cross-Border Health Care in the EU and the Organization of the National Health Care Systems of the Member States: the Dynamics Resulting from the European Court of Justice's Decisions on Free Movement and Competition Law', (2009) 26 Wisconsin International Law Journal 705; J. W. Van De Gronden, E. Szyszczak, U. Neergaard and M. Krajewski, Health Care and EU Law (Springer-Verlag New York Inc, 2011); F. Pennings, 'The Cross-Border Health Care Directive: More Free Movement for Citizens and More Coherent Law', (2011) 13 European Journal of Social Security 424; S. de la Rosa, 'The Directive on Cross-Border Healthcare or the Art of Codifying Complex Case Law', (2011) 49 Common Market Law Review 15.

${ }^{30}$ Cases 286/82 and 26/83 Graziana Luisi and Giuseppe Carbone v Ministero del Tesoro [1984] ECR 377 para 16.

31 Case C-159/90 The Society for the Protection of Unborn Children Ireland Ltd $v$ Stephen Grogan and Others [1991] ECR I-4685 paras 18-21.

32 Case C-158/96 Raymond Kohll v Union des caisses de maladie [1998] ECR I-1931 paras 20-21; See also Case C-120/95 Nickolas Decker v Caisse de maladie des employés privés [1998] ECR I-1831concerning free movement of goods. 
provider, wherein the patient pays the real cost of the treatment to the provider abroad. ${ }^{33}$

For that reason, free provision of services rules apply even to systems like the UK (English) National Health Service (NHS) which are, generally, free of charge for the entire resident population. ${ }^{34}$ Strangely enough, it seems that the free provision of services rules apply also in cases of obtaining unplanned health care during temporary stay abroad, although, in those situations, the patient does not, necessarily, pay the real market value of the treatment on the spot. ${ }^{35}$

The application of free provision of services rules of EU primary law creates a new route for patients to travel from the competent (home) state specifically to obtain health care in another Member State that is covered by the competent state's social security system. This new internal market case-law route is based on the patient paying for the treatment by him/herself to the foreign provider, and claiming reimbursement afterwards, on basis of competent state tariffs. ${ }^{36}$ In case the competent state rules provide for a higher coverage than the state of treatment rules, the patient is entitled to the difference between those two amounts (up to the level of actual cost of the treatment) in cases where the competent state unlawfully refused to give prior authorisation to the patient in question. ${ }^{37}$

Furthermore, under the free provision of services rules, patients are entitled to obtain health care in another EU Member State without obtaining prior authorisation in some instances, such as non-hospital treatments not involving major medical equipment and in cases of urgency. ${ }^{38}$ In addition to that, under EU primary law on services, patients may access any state of treatment provider, while under the coordination system they can only access those providers who are attached to the state of treatment social security health-care system (either independently contracted or employed by that system). Also, under the internal market rules, the patient is entitled to the reimbursement of travel and accommodation (outside the treating hospital) the costs if that right is granted for treatment within the competent state, thereby, avoiding discriminatory treatment of foreign-obtained health care. ${ }^{39}$

What is even more important, from the point of view of the European social citizenship, is the idea of the individual patient's entitlement that has underpinned the Court of Justice patient mobility jurisprudence. According to the Court of Justice, authorisation must be granted according to the same conditions under the

33 Case C-372/04 The Queen on the Application of Yvonne Watts v Bedford Primary Care Trust, Secretary of State for Health [2006] ECR I-4325 para 90; Although, as a possible basis for a wider interpretation of free provision of services rules and their applicability, see Case C-157/99 BSM Geraets-Smits $v$ Stichting Ziekenfonds VGZ and HTM Peerbooms v Stichting CZ Groep Zorgverzekeringen [2001] ECR I-5473 para 58 and Case C-255/09 European Commission v Portuguese Republic (ECJ 27 October 2011) para 50 .

34 See National Health Service Act 2006 Chapter 41, as amended, s 1.

${ }^{35}$ Case C-211/08 European Commission v Kingdom of Spain [2010] ECR I-5267 para 50.

${ }^{36}$ Kohll, op cit $\mathrm{n} 32$ supra, at para 27.

37 See Case C-368/98 Abdon Vanbraekel and Others v Alliance Nationale des Mutualités Chrétiennes (ANMC) [2001] ECR I-5363 para 53 and Commission v France, op cit n 26 supra, at paras 51-52.

38 See to that effect Case C-385/99 V.G. Müller-Fauré v Onderlinge Waarborgmaatschappij O.Z. Zorgverzekeringen U.A. and E.E.M. van Riet v Onderlinge Waarborgmaatschappij ZAO Zorgverzekeringen [2003] ECR I-4509 paras 81-95, Elchinov, op cit n 27 supra, at paras 43-51 and Commission v France, op cit $\mathrm{n} 27$ supra, at paras $27,42$.

39 Watts, op cit n 33 supra, at paras 139-140; confirmed by the Court in Case C-466/04 Manuel Acereda Herrera v Servicio Cántabro de Salud [2006], ECR I-5341 para 38. 
coordination regulations and under the free provision of services. Under the coordination rules, the authorisation must be given when the treatment in question is among the benefits provided for by the legislation in the Member State where the person resides and where he/she cannot be given such treatment within a time limit which is medically justifiable, taking into account his/her current state of health and the probable course of his/her illness. According to the Court, within the internal market context, the approval may be withheld when 'it is apparent that treatment which is the same or equally effective for the patient can be obtained without undue delay in his Member State of residence.' These two rules are to be interpreted in the same way. ${ }^{40}$

The Court of Justice prioritises the individual patient's entitlement to receive the best possible health care. Other considerations, especially opportunity costs, cost containment via waiting lists and Member States' need to set priorities for spending their limited resources, come second if a patient's medical condition requires a foreign treatment. ${ }^{41}$ The Court of Justice, therefore, adopted an approach which has been analysed in the literature as giving individual patient claimants 'negative, civil and substantive' rights, directly enforceable in front of the courts, as opposed to 'positive, social and procedural' ones. The latter are not absolute in a sense they are dependent on policy choices made by the state. ${ }^{42}$ These issues will be further elaborated in the following section.

The problems that emerge from this largely unsolicited approach which creates rights that Member States did not anticipate and might not be able to fund have been the subject of some investigation by social scientists. What they find is that Member States have considerable resources to delay and minimise implementation of EU health-care law. ${ }^{43}$ Their preference for "contained compliance' ${ }^{44}$ suggests that they are unwilling or unable to solve the contradictions of social citizenship rights in a diverse EU.

\section{Patient Mobility Directive}

The third constituent element of the cross-border health care EU legal framework is the Patient Mobility Directive. This Directive mostly codifies the underlying concepts of the Court of Justice jurisprudence. Its legal basis is Article 114 TFEU, which empowers the EU to harmonise its internal market. This is logical, since internal market rules are applicable to cross-border health care. Article 168 TFEU is also mentioned, since a high level of human health protection must be ensured in all EU activities and policies. ${ }^{45}$

40 Watts, op cit n 33 supra, at 60-61, 65.

${ }^{41}$ See to that effect Watts, op cit n 33 supra, at para 120.

42 Newdick, 2009, op cit n 20 supra, at 847, 857.

${ }^{43}$ I. Glinos, R. Baeten, and H. Maarse, 'Purchasing Health Services Abroad: Practices of Cross-Border Contracting and Patient Mobility in Six European Countries', (2010) 95 Health Policy 103; S. Greer and S. Rauscher, 'Destabilization Rights and Restabilization Politics: Policy and Political Reactions to European Union Health Care Services Law', (2011) 18 Journal of European Public Policy 220; A. Obermaier, The End of Territoriality? The Impact of ECJ Rulings on British, German and French Social Policy (Ashgate, 2009). S. Greer and H. Jarman, 'Managing risks in in EU health services policy: Spot markets, legal certainty and bureaucratic resistance', (2012) 22(3) Journal of European Social Policy $259-272$

44 L. Conant, Justice Contained: Law and Politics in the European Union (Cornell University Press, 2002).

45 Preamble to Directive 2011/24/EU of the European Parliament and of the Council of 9 March 2011 on the application of patients' rights in cross-border healthcare [2011] OJ L88/45 (hereinafter: Patient Mobility Directive) paras 1-2. 
Member States can still require prior authorisation in cases of hospital (overnight stay) and other cost-intensive treatments, health hazards and unsuitable providers. This is, generally, stricter for the patients than the Court of Justice jurisprudence, meaning that Member States have additional possibilities to use prior authorisation than has been provided by the case-law. ${ }^{46}$

Furthermore, the Directive is still based on the existing conflict of laws logic, with the competent state (state of affiliation) rules on coverage being applicable (up to the level of the actual treatment cost; the Member State of affiliation may cover more than that if it wants to, but is not under a duty to do so). The patient is obliged to pay upfront for the treatment and claim the Member State of affiliation's reimbursement upon his/her return there unless the Member State of affiliation decides to pay directly. ${ }^{47}$

In accordance with the case-law, patients can access any provider who is providing health care in the state of treatment. This includes providers who are not affiliated to the state of treatment social security system. The Patient Mobility Directive diverges from case-law by allowing the Member States additional grounds for refusing authorisation and/or reimbursement. ${ }^{48}$

Coverage of travel and accommodation costs has been left ambiguous. It seems the Directive grants discretion to the Member States to decide whether they should reimburse travel and accommodation costs, or not, at least in its normative part (although the Preamble, at para 34, suggests that the Member States' autonomy only applies in cases where there is no coverage of domestic travel and accommodation costs). ${ }^{49}$

Finally, the Patient Mobility Directive shall, according to its Article 2, apply without prejudice to the coordination regulations. According to the Article 8(3) of Directive 2011/24, when the conditions for the application of coordination regulations are met with respect to requests for prior authorisation, the authorisation is to be granted in accordance with the regulations, unless the patient requests otherwise.

As we can see, there are in fact three routes of accessing socially covered health care outside the state of social protection. How the Court will resolve the apparent differences between the case-law applying the Treaty and the Patient Mobility Directive remains to be seen. Those three routes (social security coordination, free movement of services case-law and Patient Mobility Directive) may be summarised as follows in Table 1:

\section{Rules for Health Care Rights}

Once the Court had developed the right to cross-border health-care access as a service, it opened up the questions that flow from any attempt to establish social citizenship rights in the institutional structure and diverse economy of the EU-above all, what kind of a right can the EU establish when highly diverse Member States must be asked to pay for it? This section shows the apparent answer: rules for rights. The Court has refrained from developing concrete European standards of health-care access. They would be far more costly and intrusive than would be possible. Instead,

\footnotetext{
46 Art 8, Dir 2011/24, op cit n 45 supra.

47 Art 7(4), ibid.

48 Art 3, 7-8, ibid.

49 Art 7(4), ibid.
} 


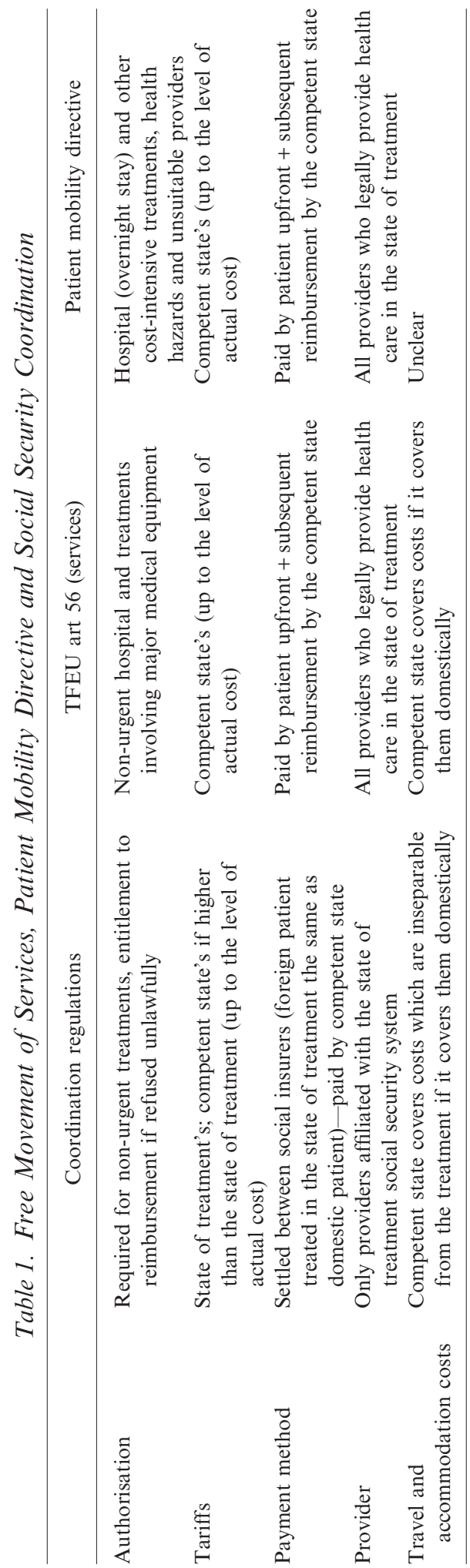


it has developed a complex framework of intertwining principles which are used to evaluate the Member States' rules regulating the area of patient mobility and, indirectly, national rules on access to socially covered health care in general.

\section{A Prior Authorisation}

The Court of Justice has allowed the Member States to retain their procedures of mandatory prior authorisation for planned health care obtained abroad by their patients (patients subject to their social security legislation) in cases of treatments which require planning of infrastructure and other resources. These are hospital treatments and other treatments which involve use of 'major medical equipment' for which a mandatory prior authorisation procedure may be applied within the context of free provision of services. In case of applying the EU coordination regulations, prior authorisation is a general rule. However, a person is entitled, in both cases, to reimbursement when he/she did not have the time to wait for the authorisation decision, due to medical urgency. Under the Article 8 of Directive 2011/24, possibilities for the Member States to impose prior authorisation are wider than under the Court of Justice jurisprudence. ${ }^{50}$ Therefore, there is no one European procedure of allowing access to foreign health care. Each of the Member States can have its own authorisation procedure, and, presumably, its own list of health treatments which involve expensive equipment and planning.

Member States, generally, remain free to develop their own systems of health care cost control, which may include waiting lists. However, within the context of giving authorisation for someone to obtain a covered health treatment abroad, the Court acknowledged that the Member States determine the priorities for treatments by themselves, but the systems they set up need to be in accordance with the notion that a patient's medical condition has priority, and there have to be mechanisms to evaluate that condition and the patient's individual needs. ${ }^{51}$ The absolute needs of the patient applying for authorisation must be given the priority by Member State, as opposed to taking into account other persons' (on a waiting lists) needs.

The Court's focus on absolute needs can be criticised. An alternative approach, which would evaluate patient's relative needs (when needs are compared with needs of other persons on waiting lists and urgency to treat their medical conditions) would be more in line with the principle of solidarity and a more realistic reflection of how welfare states budget and operate. The Court of Justice approach facilitates those patients who are capable of paying upfront for a treatment and threatening litigation in case reimbursement is refused. Furthermore, the Court of Justice approach facilitates those patients whose needs may be less urgent than needs of those persons who are unfit to travel or are just unaware of the possibilities the EU law has given them. ${ }^{52}$

Member States retain their autonomy to fix the authorisation procedure itself, in all relevant cases. The Court of Justice has not set fixed concrete procedural standards on the EU level for the procedure on the Member State level. It, rather, stated that the prior authorisation scheme must be based on objective, non-discriminatory criteria

\footnotetext{
${ }^{50}$ See to that effect Müller-Fauré, op cit n 38 supra, at paras 81-95, Elchinov, op cit n 27 supra, at paras 43-51 and Commission v France, op cit n 27 supra, at paras 27-42.

${ }^{51}$ Watts, op cit n 33 supra, at paras 67-69 and Elchinov, op cit n 27 supra, at paras 43-51; See, also, Art 8, Dir 2011/24, op cit $\mathrm{n} 45$ supra.

${ }^{52}$ See also Newdick (2006), op cit n 29 supra, at 1662.
} 
known in advance, in a way that the national authorities' discretion is not used arbitrarily, and must be based on a procedural system which is easily accessible and capable of ensuring that a request for authorisation is handled objectively and impartially within a reasonable time and refusals to grant authorisation must be capable of being challenged in judicial or quasi-judicial proceedings. ${ }^{53}$

Therefore, no concrete deadlines or required body of evidence are defined by the Court of Justice. The Court, instead, established principles by which to judge the Member States' procedures. The prior authorisation scheme is a clear example of a 'rules for rights' approach, whereby no concrete European standards for access to health care abroad are established (including no concrete limit on national waiting times). Instead, the Court has developed principles on how to evaluate national prior authorisation frameworks.

\section{B Payment Method}

The Court of Justice has not established a common European basket of covered health care. This means that the Member States are free to decide three things for themselves: the percentage of real cost of a health treatment they will socially cover (the rest of it being paid for by the patient or supplementary insurance); the number of (categories) of persons covered by national social security legislation; and the range of health-care services (types of treatments and medicinal products) covered by national social security legislation. ${ }^{54}$

All the above-mentioned dimensions of coverage remain within the ambit of the Member States' autonomy, as part of their 'freedom to organise their social security systems. ${ }^{.55}$ However, in exercising that freedom, Member States must respect the core principles of EU, especially prohibition of discrimination on basis of nationality. ${ }^{56}$

As just demonstrated, the Member States are free to define by themselves the health-care services they will pay for, and the percentage of costs of a certain service they will cover. According to the EU coordination regulations, which determine the applicable national social security legislation in cross-border situations, the state of treatment rules apply in cases where a person goes outside the state of his/her social protection or residence for a specific purpose of obtaining health care. ${ }^{57}$ This means that for a treatment which costs $€ 1.000$, and the legislation of the state of treatment covers at $80 \%$, the patient must pay $€ 200$ out of his/her own pocket.

The Court of Justice has, by applying internal market free provision of services rules in the area, developed an alternative conflict of laws rule (which has also found its way into the Patient Mobility Directive). Under this rule, a patient is entitled to obtain foreign health-care treatment according to the competent state rules and tariffs (tariffs for an equivalent domestic treatment). Therefore, in case the competent state covers $60 \%$ of the treatment, the patient will pay the entire $€ 1.000$ sum to the

\footnotetext{
${ }^{53}$ Müller-Fauré, op cit n 38 supra, para 85; See, for a similar rule explicitly prescribed, Art 9, Dir 2011/24, op cit n 45 supra.

54 S. Smith, 'The Irish "Health Basket": A Basket Case?' (2010) 11 European Journal of Health Economics $343,344$.

55 Kohll, op cit n 32 supra, at paras $17-18$.

56 See, for instance, Case 238/82 Duphar BV and Others $v$ The Netherlands State [1984] ECR 523 para 22 , on the depth of the coverage, namely the lists of medicinal products (drugs) excluded from national social security package.

57 Art 20, Reg 883/2004, op cit n 25 supra.
} 
provider, and then claim the refund of $€ 600$ when he/she returns home. ${ }^{58}$ Of course, this is a simple scenario, in which the competent state and the state of treatment's equivalent treatments cost exactly the same. This does not always have to be the case. Furthermore, there may be no equivalent treatment in the competent state, which makes the calculation of the reimbursement even more difficult.

Free provision of services rules, as interpreted by the Court of Justice, provide an additional possibility to patients who are refused prior authorisation, according to EU coordination regulations, unlawfully. In those instances, the patients are entitled to the higher competent state coverage, up to the level of actual cost of the treatment. This means that, if the competent state's treatment costs $€ 1.100$, and is covered there fully $(100 \%)$, while the state of treatment covers $80 \%$ of the treatment which costs $€ 1.000$, the competent state will reimburse $€ 1.000$ to the patient. The entitlement to the more beneficial competent state reimbursement has, in the meantime, become an explicit part of the EU coordination rules. ${ }^{59}$

It can be concluded, regarding payment methods, that the Court of Justice does not engage in defining by itself the level of social security health coverage of cross-border health-care treatments. It has limited itself into obliging Member States to provide for an additional possibility for patients, to be covered under more beneficial domestic (competent state) tariff. Again, we can see the 'rules for rights' approach, whereby there is no common European standard of the level of coverage but a principle that the Member States must apply most favourable rules for patients accessing health care abroad. Unsurprisingly, this approach has not simplified access to health care. To the contrary, it has established parallel systems, with different distributional and policy consequences and unclear borders.

\section{Travel and Accommodation Costs}

The Court explained the coverage of travel and accommodation (other than the treating hospital itself) costs in Watts. The coordination rules do (did) not entitle the patient to coverage of these costs, but he or she can claim them on the basis of the free provision of services rules. ${ }^{60}$ Since, under the internal market rules, the competent state provisions are applicable, the patient is entitled to the reimbursement of travel and accommodation costs if that right is granted for treatment within the competent state (thus avoiding disadvantageous treatment of health care abroad). The Patient Mobility Directive remains ambiguous in this respect. ${ }^{61}$

As we can see, the patients are not generally entitled to coverage of travel and accommodation costs under the EU law. The Court of Justice has limited itself to imposing an obligation upon Member States not to treat treatments obtained abroad differently from treatments obtained from domestic providers. Therefore, the latter principle of treating foreign treatments equally is used to judge the legality of Member States' regulatory framework on cross-border health care, with respect to travel and accommodation costs.

\footnotetext{
58 Watts, op cit n 33 supra, at paras 124-131; See, also Art 7(4), Dir 2011/24, op cit $\mathrm{n} 45$ supra.

59 Vanbraekel, op cit $\mathrm{n} 37$ supra, at para 53; Watts, op cit $\mathrm{n} 33$ supra, at para 131. See, also, Art 26(7), Reg 987/2009, op cit n 25 supra.

${ }^{60}$ Watts, op cit $\mathrm{n} 33$ supra, at paras 138-139. See, also, Art 26(8), Regulation 987/2009, op cit $\mathrm{n} 25$ supra.

${ }^{61}$ Watts, op cit $\mathrm{n} 33$ supra, at paras 139-140; confirmed by the Court in Acereda Herrera, op cit $\mathrm{n} 39$ supra, at para 38; See, also, Art 7(4), Dir 2011/24, op cit n 45 supra.
} 


\section{Range (Depth) of Health Care Covered}

As noted above, the Member States are free to determine the range of health care (treatments) their social security systems cover. There is no common European package of health-care entitlements. The Court of Justice 'rules for rights' approach increasingly affects Member States' determinations as well. In Geraets-Smits, the Court of Justice emphasised that the European law (internal market provisions on services) does not require the Member States to extend the package of health-care services they pay for. Therefore, a patient who obtains a planned health care outside the competent state is not entitled to its coverage if that treatment is not part of the competent state's social package, even if it is a part of state of treatment social package. ${ }^{62}$

An explicit provision stating the same limitation is contained within the coordination regulations related to the state of residence of a patient travelling abroad to obtain health care. The insertion of this provision (into the previous Regulation 1408/71) has happened as a direct result of the Court of Justice case-law, which tried to establish a patient entitlement to most effective health care anywhere within the EU. ${ }^{63}$ As we can see, the Court of Justice allows the same limitation to social citizenship within the framework of EU internal market law.

However, the Member States' freedom to define their social security packages is not absolute. The criteria for putting a medicinal product or a treatment within the ambit of covered health care must be non-discriminatory, not referring to the origin of a medicinal product, or a provider. If a Member State uses notions like 'normal treatments,' instead of concrete detailed lists of covered treatments as criteria for delimiting the scope of its coverage, those notions must be interpreted in a way which does not exclude treatments not provided on the competent state's territory. Therefore, 'normal treatments' must be interpreted as treatments defined as such by international medical science. ${ }^{64}$

The full repercussions of the Court of Justice's logic in Geraets-Smits, including the difficulty of identifying international medical science, could not have been entirely visible at the time. However, the Court further clarified its position in Elchinov. There the Court stated, with respect to giving authorisation for foreign treatment under coordination regulations that when national legislation contains broad definitions rather than detailed lists of precise covered health-care treatments, the national social security system is obliged to cover the most effective health treatment available within the EU, which falls within those national definitions, even if that treatment is not provided on the territory of the competent state. ${ }^{65}$

The described jurisprudence has also been incorporated into the Patient Mobility Directive. The Directive tries to reconcile the Court of Justice's extensive interpretations with the Member States' autonomy to define their health cover. Thus, the

62 Geraets-Smits, op cit $\mathrm{n} 33$ supra, at para 87.

${ }^{63}$ Art 20, Reg 883/2004, op cit n 25 supra; The insertion of the limitation was carried out via Council Regulation (EEC) 2793/81 of 17 September 1981 amending Regulation (EEC) No 1408/71 on the application of social security schemes to employed persons and their families moving within the Community and Regulation (EEC) 574/72 fixing the procedure for implementing Regulation (EEC) No 1408/71 [1981] OJ L275/1, as a result of the Court judgement in Case 117/77 Bestuur van het Algemeen Ziekenfonds Drenthe-Platteland v G. Pierik [1978] ECR 825.

${ }^{64}$ Geraets-Smits, op cit $\mathrm{n} 33$ supra, at paras 88-98.

${ }^{65}$ Elchinov, op cit n 27 supra, at paras 67, 73. 
Preamble of the Directive clearly says that the Directive does not extend national coverage. ${ }^{66}$ Then, it reiterates the Court of Justice approach in Elchinov. ${ }^{67}$ This is followed by the Directive's normative part, containing a special recognition of Member States' freedom to define health care for which an insured person is entitled to assumption of costs, 'whether at a local, regional or national level' (a similar notion also present in the Preamble). ${ }^{68}$ Interpreting all this could keep many lawyers employed for a long time.

Member States, such as the UK, where only a general duty of the government to promote comprehensive health service (with some more specific provisions as regards certain services) is prescribed by statutes, would, according to the Court of Justice, have to cover any health treatment in the EU which could improve, to some extent, an individual patient's condition. ${ }^{69}$

There are few critical remarks which can be made regarding the Court of Justice approach in this area. First, the principles established to judge national rules on patient mobility are not adapted to the specific context of some Member States. In the UK (England), health care as of 2011 is organised in a way that local purchasers of health care called Primary Care Trusts (PCTs) are allocated annually a certain amount of money, which they further allocate according to the needs of their local population. Therefore, the extent of covered treatments is, generally, not defined by national statutes or ministerial decrees provided by statutes but on the level of local policy making by relevant local bodies. ${ }^{70}$

The systems which do not use detailed national legislative lists of covered treatments might find themselves obliged to cover more foreign health care than those which use those lists. Logically, this means that patients from the systems which use detailed lists are put in a position which is not equal in terms of accessing foreign health care, with the position of the patients from systems which do not use such lists.

Second, since Member States are still free to define coverage by themselves, nothing prevents them from maintaining their autonomy by introducing detailed closed lists. This is a major flaw of the 'rules for rights' approach, since it creates an incentive for the Member States to impose limitations which will be in accordance with the EU law but still limit European social citizenship. The crucial standard used by the Court of Justice to judge Member State standards is non-discrimination, as demonstrated above. The non-discrimination standard, however, does not correspond well with social rights. Social rights, unlike negative civil rights, require a positive action on part

${ }^{66}$ Preamble to Dir 2011/24, op cit n 45 supra, at para 33.

67 ibid, at para 34.

${ }_{68}$ Art 7(3), Dir 2011/24, op cit n 45 supra; ibid, at para 33.

${ }^{69}$ See NHS Act 2006, op cit n 34 supra, s 1-4 and Schedule 1.

70 NHS Act 2006, ibid, s 18-24A and Health Committee, 'Commissioning: further issues_Fifth Report of Session 2010-2011 Volume II' HC (2011) Ev 84; See also K. Syrett, 'Mixing Private and Public Treatment in the UK's National Health Service: A Challenge to Core Constitutional Principles?' (2010) 17 European Journal of Health Law 235, 239; It seems that the Dir 2011/24, op cit n 45 supra, is more adapted to the needs of Member States using local commissioning. See Preamble to the Dir 2011/24, op cit $\mathrm{n} 45$ supra, at para 44 and Art 7(3) Dir 2011/24, op cit $\mathrm{n} 45$ supra. There are some negative list of excluded (not covered) medicinal products and positive lists of prescribed appliances in the English legal system; See to that effect National Health Service (General Medical Services Contracts) (Prescription of Drugs etc.) Regulations 2004 SI 2004/629, as amended and Department of Health (UK-England), 'The NHS (Pharmaceutical Services) Regulations 2005-Information for Primary Care Trusts - revised September 2009' (2009) 7-8. 
of the Member States' policy makers. ${ }^{71}$ That action can be equalisation in two directions: either equalisation on higher level or equalisation on lower level.

Member States can limit their rules on coverage in general in order to prevent an EU law-imposed obligation to cover very expensive foreign treatments (even under foreign tariffs, according to the EU coordination regulations). However, excluding only specific treatments which are not available domestically could, presumably, be hard to justify to the Court of Justice as non-discriminatory. Therefore, the Member States may resort to excluding broader categories of treatments from their coverage, categories including both treatments available domestically but also the more expensive treatments available only abroad (for example, in vitro fertilisation, which the UK rations for a variety of clinical and ethical reasons but which is widely available in southern Europe). Reducing the coverage of health-care systems is not a step forward for social citizenship.

Third, the fact that the Court of Justice introduces a common European standard of effectiveness (according to international science), may seem to go a bit further than the 'rules for rights' approach identified in this article. This European standard is given priority in a sense that an individual is entitled to a most effective health care for his/her individual condition within the framework of national social security coverage broadly interpreted. The problem is that the rules for rights approach might still rule out health policies that look ethical and sensible but violate the emerging rules.

An example of the latter problem is the standard of Quality Adjusted Life Years (QALY) which is an index of survival that is adjusted to account for the patient's quality of life during this time, or, in other words, number of extra months or years of life of a reasonable quality a person might gain as a result of treatment. ${ }^{72}$ This standard is used by the National Institute for Health and Clinical Excellence, which evaluates new medical technologies on cost-effectiveness basis for the English NHS, and whose positive evaluation means the PCTs must allocate part of their resources to fund the approved treatment. ${ }^{73}$

If an extremely expensive treatment may prolong one's life for two months, should it be covered or not? According to the Court of Justice logic of giving priority to absolute needs, the answer is affirmative. However, the problem is that social security is not only about patients who seek treatments abroad but also affects other patients whose treatments will not be funded, or the funding will be delayed, because of the EU law obligation to cover the foreign treatment. What legal (legislative) technique should be used by the Member States to implement standards like QALYs within their systems?

The application of the effectiveness standard in the area of social citizenship highlights another distinction between the positive social rights and generally negative rights of free movement (negative in a sense that the Member States must refrain from imposing obstacles to free movement across Member States borders).

\footnotetext{
71 See for a similar discussion Newdick (2009), op cit n 20 supra, at 847, 857.

72 National Institute for Health and Clinical Excellence, 'Guide to the Methods of Technology Appraisal' (2008, updated 2009) 74.

73 Syrett, op cit n 70 supra, at 239, 244. See also Directions to Primary Care Trusts and NHS trusts in England concerning Arrangements for the Funding of Technology Appraisal Guidance from the National Institute for Clinical Excellence (NICE) 2003, as amended.
} 


\section{Can We have Rules for Rights?}

The 'rules for rights' approach responds to the problem of establishing social citizenship rights in an EU where the diverse Member States, rather than the regulatory EU, must pay for and provide the actual content of rights. It does that not by establishing a traditional social citizenship right to equal access but rather by setting the rules within which Member State governments define the social citizenship rights of their own citizens. The approach sidesteps political, legal, managerial and financial problems that emerge from any effort to harmonise social rights and the bureaucracies that deal with them. It accepts inequality between states, and tries to make it more transparent so that citizens, businesses and policy makers know what they can do. The process of creating greater clarity, such as a basket of services, might even produce valuable deliberation. Above all, it escapes the problem that any regulatory polity, including the EU, risks: that of mandating social rights that might sound good but do not necessarily reflect the preferences and capabilities of different Member States and their citizens.

\section{A Problems}

Nevertheless, there are both practical and theoretical problems. The first problem is practical: the rules might block some good health policies and promote some debatable ones. It creates incentives for those states to impose limitations upon free movement. Since social rights are an area where Member States' activity, rather than inactivity is required, concerned states may always opt for non-discriminatory inactivity by generally not funding certain medical procedures without any reference to the place (state) where the treatment is provided. National health service systems such as the UK, which rely on gatekeeping rather than on baskets of services, would face even more perverse organisational consequences. Traditionally, their definition of a necessary service for an individual patient is a joint product of the doctor's advice and the health services' investment - the doctor could recommend the treatment, but if it had been decided that it would not be provided in any significant amount, the patient wouldn't get it. If we translate the logic of gatekeeping into 'rules for rights,' then patients could have any treatment their doctors recommended-with bad consequences for equity (since doctors' and patients' assertiveness differs, and the costs would be taken out of other areas of health care) and for financial control in the health service.

Second, 'rules for rights' can produce rigidity. If states' only option is a clear, even legislative, statement of entitlements, then there is going to be a constant tension between technological advance, patient needs and the laggard rules. The reason Member States do not use detailed legislative health entitlements is that they would always be incomplete, politicised, outdated and probably contradictory over time. So if states have to create rules for rights, the logical effects will be vague rules and constant complaints that the rules are unnecessarily blocking necessary treatment.

Third, and possibly most important, 'rules for rights' sidesteps the content of social citizenship as well as its problems. What kind of European social citizenship is it if it adheres to the Member States and it is largely deferential to their finances and policy decisions? Not the Marshallian one that creates islands of equality, such as equal access to health care, in a sea of inequality. Instead, 'rules for rights' reasserts the connection between Member States, their social citizenship rights and their citizens. It 
instead subjects to EU law the states' determinations about the form in which those rights are identified, the broadest outlines of such rights and directly, their applicability across borders. This is not an EU social citizenship; it is rather an EU framework for Member State social citizenship.

\section{B Experimentalism as Solution?}

If there is to be an EU social citizenship, it will have to erode rather than enshrine the differences in the capacity and willingness of Member States to provide social citizenship rights. It is unlikely that the sums of money or the tidal shift in public opinion needed to establish European social citizenship rights will appear, so the question is what to do in the meantime. What kinds of approaches are compatible with the law and yet avoid or reduce the practical problems and create some kind of social citizenship? The answers to this question come from and apply to more than health care. There are other policy areas that have the combination of bureaucratic complexity, highly individualised user experiences and large costs - social care, education and local government among others.

One possible solution would lie in experimentalist governance. ${ }^{74}$ This could but does not necessarily mean the Open Method of Coordination. ${ }^{75}$ It might rather mean the development of networks between Member State authorities that can refine expectations for social rights in a way the law recognises. This would be, conceptually, a two-step process of first identifying responsible authorities in Member States that can take responsibility for the scope and detailed definition of social citizenship rights, followed by networking between them to establish reasonable shared definitions that would work in practice. Responsible authorities that could bridge between the administrative and political realities of their Member States and the outlines of EU law might be able to provide a more realistic, if less theoretically clear, definition of EU citizens' real rights that would reduce the trade-off between patient mobility and a stable, solidaristic health system within countries. ${ }^{76}$ If we return to the example of competition law, part of the reason that the field works as well as it does is the

${ }^{74}$ C. Sabel and J. Zeitlin, 'Learning from Difference: The New Architecture of Experimentalist Governance in the European Union', (2007) 14 European Law Journal 271; C. Sabel and J. Zeitlin, Experimentalist Governance in the European Union: Towards a New Architecture (Oxford University Press, 2010); T. Hervey, "Adjudicating in the Shadow of the Informal Settlement?": The European Court of Justice, "New Governance" and Social Welfare', in G. Letsas and C. O'Cinneide (eds), Current Legal Problems (Oxford University Press, 2010), at 92; G. de Búrca and J. Scott, 'Introduction: New Governance, Law and Constitutionalism', in G. de Búrca and J. Scott (eds), Law and New Governance in the EU and US (Hart, 2006), at 1; J. Scott and S. Sturm, 'Courts as Catalysts: Rethinking the Judicial Role in New Governance', (2007) 13 Columbia Journal of European Law 565 .

75 M. Ferrera, 'National Welfare States and European Integration: In Search of a "Virtuous Nesting", (2009) 47 Journal of Common Market Studies 219.

${ }^{76}$ For other examples of such networks working in EU health policy, see S. Greer, 'The Weakness of Strong Policies and the Strength of Weak Policies: Law, Experimentalist Governance, and Supporting Coalitions in European Union Health Care Policy', (2011) 5 Regulation \& Governance 187; L. Trubek, T. Oliver, C. Liang, M. Mokrohisky and T. Campbell, 'Improving Cancer Outcomes through Strong Networks and Regulatory Frameworks: Lessons from the United States and European Union', (2011) 14 Journal of Health Care Law and Policy 119; S. Greer and P. Kurzer (eds), European Union Public Health Policy: Regional and Global Perspectives (Abingdon: Routledge, 2013). 
existence of a professionalised network of European competition regulators who share approaches, principles and techniques. ${ }^{77}$

Health-care services have the same basic characteristics for the success of new governance, per Sabel and Zeitlin's analysis: the problems are clear and defined by law; the solution is not agreed; and the various policy problems that they create are enough to give every policy maker an interest in stabilising expectations. ${ }^{78}$ The case for a strategic response that builds networks between responsible authorities is strong: it can work insofar as it fulfils Sabel and Zeitlin's list of conditions; it would start to solve the practical problems of rigidity and bad incentives; it would presumptively gain the advantages of learning by monitoring that Sabel and Zeitlin stress; and it would thereby have a chance to identify spaces for possible development of European social citizenship.

\section{Conclusion}

The limitation of EU social policy as it stands today is clear: much of it is driven by courts and cases with legislation often hobbled by weak treaty bases and political dissensus. That means it lacks political support and, often, sympathy for the detailed practical and financial problems policy-makers face. As a result, it creates practical and political problems that the Court has been avoiding by applying 'rules for rights,' which create new practical problems and vacate EU social citizenship of much of its meaning. The logical solution would be a larger and more redistributive EU budget, which seems unlikely. Barring that, there is some hope that experimentalist governance tools, networking agencies involved in coverage determinations in the Member States, could reduce the contradictions between Member States' diversity and the claims of European citizenship. So there we stand: EU law on health care, and the model of social citizenship more generally, is not social citizenship that creates islands of equality between citizens. Rather, what passes for European social citizenship is a set of rules governing Member States' own social citizenship rights.

First submission: October 2011 Final draft accepted: March 2012

\footnotetext{
77 M. Cini and L. McGowan, Competition Policy in the European Union (Palgrave Macmillan, 2nd edn, 2009).

78 Sabel and Zeitlin, op cit n 70 supra
} 